\title{
Comparative study of intravenous iron sucrose versus ferric carboxymaltose for the treatment of iron deficiency anemia in postpartum patients
}

\author{
Kishorkumar Vitthal Hol*, Hemant Damle, Gulab Singh Shekhawat, Asha Hol
}

\begin{abstract}
Department of Obstetrics \& Gynecology, Smt Kashibai Navale Medical College, Narhe, Ambegaon, Pune-411041,
\end{abstract} Maharashtra, India

Received: 09 March 2015

Revised: 19 March 2015

Accepted: 19 April 2015

\section{*Correspondence: \\ Dr. Kishorkumar Vitthal Hol, \\ E-mail: drhol@rediffamil.com}

Copyright: () the author(s), publisher and licensee Medip Academy. This is an open-access article distributed under the terms of the Creative Commons Attribution Non-Commercial License, which permits unrestricted non-commercial use, distribution, and reproduction in any medium, provided the original work is properly cited.

\begin{abstract}
Background: Objectives: To study the efficacy and safety of intravenous iron sucrose versus ferric carboxymaltose in the treatment of iron deficiency anaemia in postpartum patients.

Methods: Well compensated anemic postpartum patients with $\mathrm{Hb}$ between $7-11 \mathrm{gm} \%$ at 24 hours after delivery were included in the study. Patients were thoroughly investigated for hematological parameters. All patients were checked for hemoglobin and serum ferritin at 24 hours after delivery and 42 days after delivery. Each patient in mild and moderate anemia group has received a fixed dose of $500 \mathrm{mg}$ and $1000 \mathrm{mg}$ respectively of both compounds. All other iron supplements (except from diet) were withheld during follow up period.

Results: Average rise in $\mathrm{Hb}$ in mild anemia group is $2.30 \mathrm{gm} \%$ with iron sucrose and 2.52 gm\% with ferric carboxymaltose after 42 days of infusion. In moderate anemia group average $\mathrm{Hb}$ rise observed is 4.58 gm\% with iron sucrose and $4.73 \mathrm{gm} \%$ with ferric carboxymaltose after 42 days. Significant improvement in iron stores is also observed at the end of 42 days in both groups. Unpaired ' $t$ ' test was used to test the significance of rise and compare the rise between two groups. Both compounds have shown similar response and difference between them is not statistically significant.

Conclusions: Fixed dose iron sucrose and ferric carboxymaltose are equally effective and safe for the treatment of iron deficiency anemia in postpartum patients.
\end{abstract}

Keywords: Iron sucrose, Ferric carboxymaltose, Postpartum iron deficiency anemia

\section{INTRODUCTION}

Iron deficiency anemia is very much prevalent in the tropics particularly amongst women of child bearing age, especially in under privileged population. Iron deficiency anemia is the commonest indirect cause of maternal mortality and morbidity in India. ${ }^{1}$ Anemia is estimated to contribute 20 percent of all maternal deaths and nine times higher risk of perinatal mortality. Postpartum anemia is observed in up to $27 \%$ of women. ${ }^{2}$ Postpartum anemia is associated with longer hospital stays, depression, anxiety, persistent ill health, lactation failure in mother and delayed development in infants. ${ }^{3}$

In view of fetal and maternal risk associated with iron deficiency anemia, it is obvious that treatment of anemia efficiently would lead to considerable reduction in risk factors which affect pregnancy, fetal outcome and postpartum period. Adequate and early treatment of anemia in post-partum period will have improved quality of life in women in child bearing age group. ${ }^{4}$ 
The treatment of choice for postpartum anemia depends on the severity and/or additional maternal risk factors or co-morbidities. Puerperal patients who have iron deficiency anemia are likely to have high iron requirement. ${ }^{5}$ In addition, an inflammatory reaction can occur, particularly following surgically assisted deliveries and cesarean section, leading to iron sequestration in macrophages and decrease of intestinal absorption, so that administered iron is not available for hemopoesis. ${ }^{6}$ In most of these cases oral iron is not enough since the endogenous iron stores are already depleted and less iron is provided for sufficient erythropoesis. As compliance to oral iron therapy is very poor and also the results are unpredictable, parentral iron therapy is better option to treat such patients. ${ }^{7}$ Various compounds like iron dextran (IM/IV), iron sorbitol (IM), iron sucrose (IV), ferric carboxymaltose etc. are available for parentral therapy of which iron sucrose and ferric carboxymaltose gives better results because quick binding of iron to transferrin and quick travel to bone marrow resulting in early rise in $\mathrm{Hb}^{8}$ Both these compounds are safe in post-partum period and have less chances of hypersensitivity reactions (no test dose required). ${ }^{9}$ So we have prospectively monitored the response to fixed dose IV iron sucrose and ferric carboxymaltose in a cohort of 123 postpartum patients with mild and moderate anemia over six weeks period. We have not included patients with severe anemia ( $\mathrm{Hb}<7$ gm\%) in our study, as most of these patients are hemodynamically unstable and required blood transfusion.

\section{METHODS}

It is a prospective, randomized, study without blinding. The study was conducted in dept. of Obstetrics \& Gynecology Smt. Kashibai Navale Medical College \& General Hospital, Pune from Jan 2013 to Dec 2013 after ethical committee approval. All the well compensated patients with mild and moderate anemia ( $\mathrm{Hb} 7-11 \mathrm{gm} \%)$ were included in this study; the patients were selected from those delivered in our hospital.

\section{Inclusion criteria}

1) Postpartum patients with $\mathrm{Hb}$ between 7-11 gm\% at 24-48 hours after delivery and willing to give consent.

2) Patients with iron deficiency anemia only (peripheral smear showing microcytic hypochromic picture and decreased serum ferritin levels).

\section{Exclusion criteria}

1) Any hematological disorder other than iron deficiency anemia.

2) Patients suffering from chronic illness like renal, cardiac, hepatic or immunological disorders.

3) Known hypersensitivity and resistance to injectable iron compounds.
4) Patients with severe anemia in decompensated state requiring blood transfusion.

5) Patients suffering from anemia due to acute blood loss e.g. PPH.

6) Any other serious medical illness like patients with history of asthma, thromboembolism, and signs of infection.

Written \& informed consent was taken after counseling. All the consequences \& benefits of the therapy are explained to patient. After inclusion in study detailed history of each patient was taken including age, medical history, obstetric history, menstrual history \& family history. Detailed physical examination was carried out; along with investigations like hemogram, reticulocyte count, Hct, MCV, MCHC, MCH, RDW, peripheral smear and Sr. ferritin. All the hematological parameters were done on peripheral venous blood (collected from cubital vein) by colorimetric method using automated Beckman Coulter apparatus and Serum ferritin by vaso immunochemical assay kit method.

We have included 123 patients in our study after checking all criteria's and taking consent out of which 100 patients have completed the follow up and 23 patients were lost to follow up. There were 60 patients in mild anemia group ( $\mathrm{Hb}$ 9-11 gm\%); randomly divided in two equal groups. Group A treated with $500 \mathrm{mg}$ of iron sucrose(in divided doses , $\max 200 \mathrm{mg}$ at a time every alternate day) and Group B received $500 \mathrm{mg}$ ferric carboxymaltose (as single dose) both were diluted in 100 $\mathrm{ml}$ of NS given slow IV over $30 \mathrm{~min}$ on indoor basis. Moderate anemia group ( $\mathrm{Hb} 7-9 \mathrm{gm} \%$ ) had 40 patients, equally and randomly divided into two equal half; Group A received $1000 \mathrm{mg}$ of iron sucrose (max $200 \mathrm{mg}$ at a time every alternate day) and Group B received $1000 \mathrm{mg}$ of ferric carboxymaltose ( $\max 500 \mathrm{mg}$ at a time every alternate day) both were diluted in $100 \mathrm{ml}$ of NS given slow IV over $30 \mathrm{~min}$ on indoor basis. During and 1 hour after infusion each patient was monitored on 1:1 basis in the ward for any adverse reactions. All the oral iron preparations are suspended during and after the therapy. After completion of the regimen patients were discharged from ward and followed up on the OPD basis 6 weeks from the day of completion of therapy. We have used this fixed dose regimen, because iron requirement (for erythropoesis and replenishing iron stores) when calculated by various formulas is approximately similar to our dose in both groups. Each patient was followed for $\mathrm{Hb}$ rise and serum ferritin at 6 weeks after completion of therapy; the results were noted in preformed Performa for each patient and tested stastically at the end of study by using unpaired 't' test. Any adverse drug reactions during infusion and in follow up period were recorded.

\section{RESULTS}

Actual patient recruitment started in $1^{\text {st }}$ week of Feb. 2013 after ethical committee approval. 
123 patients registered; of which 100 have completed follow up. 23 patients were lost to follow up for varieties of reasons. Baseline haematological parameters in the women lost to follow up were similar to those of the women included in the analysis. Results were encouraging with satisfactory rise in $\mathrm{Hb}$ and serum ferritin, good patient satisfaction, minimal side effects and easy administration of dose. Out of 100 patients 60 were mild anemic and 40 were moderately anemic (Figure 1). Patients studied were from all the age groups and most patients (66) were belonged to age group of 2025 years. Most of patients were multipara (78) (Figure 2).

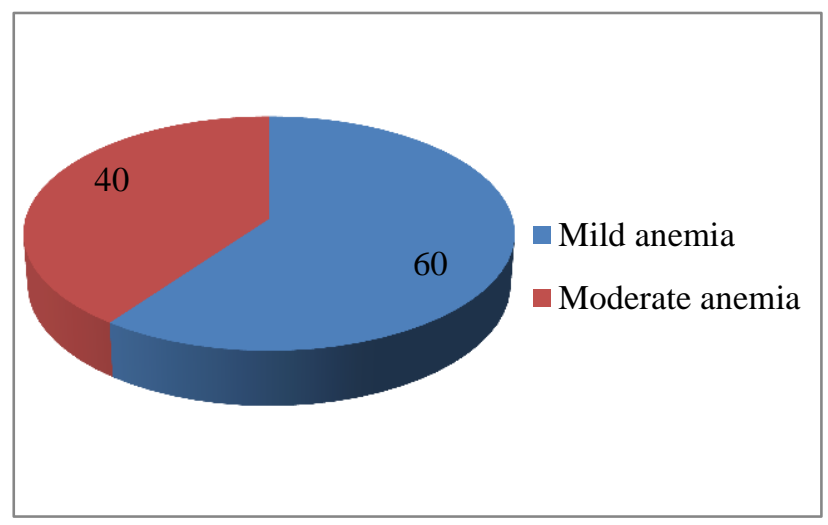

Figure 1: Distribution of patients $(n=100)$.

$60 \%$ of patients in study group were mild anemic patients as incidence of mild anemia is more.

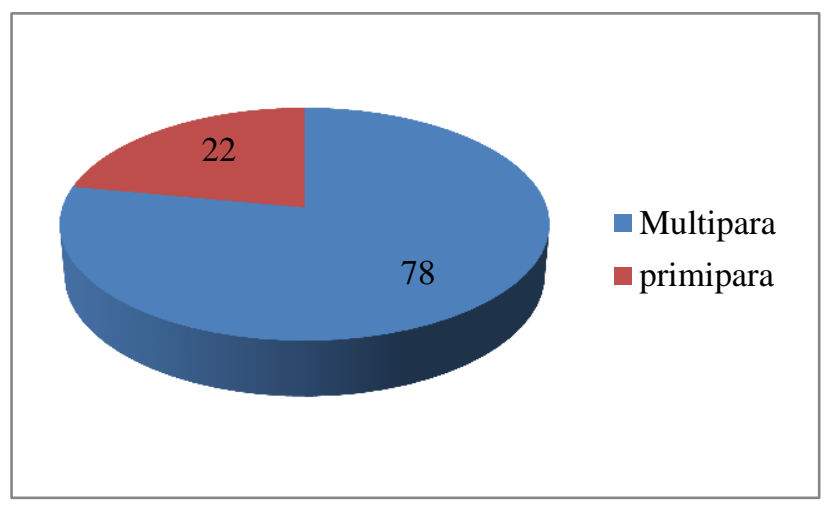

Figure 2: Distribution of patients according to parity $(\mathrm{n}=\mathbf{1 0 0})$.

Most of the patients (78\%) were multipara as anemia is more common in multiparas.

There were no significant differences in hemoglobin levels between the two groups at any of the time points studied. When progression of hematological parameters was evaluated, a significant increase was observed in hemoglobin values in each group. Indeed both groups achieved hemoglobin values above $12 \mathrm{gm} / \mathrm{dl}$ at 6 weeks (Table $1 \& 2$ ). No significant differences in serum ferritin levels between groups were observed at any time point (Table $3 \& 4$ ). No women withdrew from the trial because of adverse side effects. There were no differences observed in adverse drug reactions in both groups at any time point (Table 5). Only significant difference is observed in length of hospital stay between two groups, iron sucrose group required longer hospital stay than ferric carboxymaltose group (Table 6). Average length of hospital stay for mild anemia group is 3.5 days for iron sucrose group and 2.4 days for ferric carboxymaltose group. Patients in moderate anemia group treated with iron sucrose stayed in hospital for almost double duration than patient treated with ferric carboxymaltose.

Minor adverse reactions, which included burning at the infusion site, itching, giddiness and GI symptoms like nausea and vomiting, occurred in $15 \%$ of the women, but there were no major adverse reactions (Table 5).

Table 1: Improvement in haemoglobin (gm/dl) in mild anemia group $(n=60)$.

\begin{tabular}{|llll|}
\hline Hemoglobin & $\begin{array}{l}\text { Iron } \\
\text { sucrose } \\
\text { group } \\
\text { mean }\end{array}$ & $\begin{array}{l}\text { Ferric } \\
\text { carboxy- } \\
\text { maltose } \\
\text { group }\end{array}$ & $\begin{array}{l}\text { Difference } \\
\text { between mean }\end{array}$ \\
\hline Baseline & 9.83 & 9.94 & $\begin{array}{l}\text { Not Significant } \\
\mathrm{t}=1.358\end{array}$ \\
\hline 6 weeks & 12.14 & 12.46 & $\begin{array}{l}\mathrm{DF}=58 \\
\mathrm{P} \text { value }=0.180 \\
(95 \% \mathrm{CI}=-0.5196 \\
\text { to } 0.09959)\end{array}$ \\
\hline $\begin{array}{l}\text { Mean } \\
\text { difference }\end{array}$ & 2.31 & 2.52 & \\
\hline
\end{tabular}

Table 2: Improvement in haemoglobin $(\mathrm{gm} / \mathrm{dl})$ in moderate anemia group $(n=40)$.

\begin{tabular}{|c|c|c|c|}
\hline Hemoglobin & $\begin{array}{l}\text { Iron } \\
\text { sucrose } \\
\text { group } \\
\text { mean }\end{array}$ & $\begin{array}{l}\text { Ferric } \\
\text { carboxy- } \\
\text { maltose } \\
\text { group }\end{array}$ & $\begin{array}{l}\text { Difference } \\
\text { between mean }\end{array}$ \\
\hline Baseline & 7.75 & 7.74 & \multirow{3}{*}{$\begin{array}{l}\text { Not Significant } \\
\mathrm{t}=1.023 \\
\mathrm{DF}=38 \\
\mathrm{P} \text { value }=0.313 \\
(95 \% \mathrm{CI}=-0.4765 \\
\text { to } 0.1565)\end{array}$} \\
\hline 6 weeks & 12.36 & 12.47 & \\
\hline $\begin{array}{l}\text { Mean } \\
\text { difference }\end{array}$ & 4.58 & 4.74 & \\
\hline
\end{tabular}

Table 3: Improvement in serum ferritin (ng/ml) in mild anemia group $(n=60)$.

\begin{tabular}{|c|c|c|c|}
\hline $\begin{array}{l}\text { Serum } \\
\text { ferritin }\end{array}$ & $\begin{array}{l}\text { Iron } \\
\text { sucrose } \\
\text { group } \\
\text { mean }\end{array}$ & $\begin{array}{l}\text { Ferric } \\
\text { carboxy- } \\
\text { maltose } \\
\text { group }\end{array}$ & $\begin{array}{l}\text { Difference } \\
\text { between mean }\end{array}$ \\
\hline Baseline & 14 & 15.83 & \multirow{3}{*}{$\begin{array}{l}\text { Not Significant } \\
\mathrm{t}=0.318 \\
\mathrm{DF}=58 \\
\mathrm{P} \text { value }=0.751 \\
(95 \% \mathrm{CI}=-5.319 \\
\text { to } 3.859)\end{array}$} \\
\hline 6 weeks & 51.96 & 54.53 & \\
\hline $\begin{array}{l}\text { Mean } \\
\text { difference }\end{array}$ & 37.97 & 38.70 & \\
\hline
\end{tabular}


Table 4: Improvement in serum ferritin $(\mathrm{ng} / \mathrm{ml})$ in moderate anemia group $(n=40)$.

\begin{tabular}{|c|c|c|c|}
\hline $\begin{array}{l}\text { Serum } \\
\text { ferritin }\end{array}$ & $\begin{array}{l}\text { Iron } \\
\text { sucrose } \\
\text { group } \\
\text { mean }\end{array}$ & $\begin{array}{l}\text { Ferric } \\
\text { carboxy- } \\
\text { maltose } \\
\text { group }\end{array}$ & $\begin{array}{l}\text { Difference } \\
\text { between mean }\end{array}$ \\
\hline Baseline & 11.35 & 12.45 & \multirow{3}{*}{$\begin{array}{l}\text { Not Significant } \\
\mathrm{t}=0.271 \\
\mathrm{DF}=38 \\
\mathrm{P} \text { value }=0.788 \\
(95 \% \mathrm{CI}=-6.347 \\
\text { to } 4.847)\end{array}$} \\
\hline 6 weeks & 55 & 56.85 & \\
\hline $\begin{array}{l}\text { Mean } \\
\text { difference }\end{array}$ & 43.65 & 44.40 & \\
\hline
\end{tabular}

Table 5: Adverse drug reactions observed.

\begin{tabular}{|lll|} 
ADR & $\begin{array}{l}\text { Iron } \\
\text { sucrose } \\
\text { group }\end{array}$ & $\begin{array}{l}\text { Ferric } \\
\text { carboxy- } \\
\text { maltose } \\
\text { group }\end{array}$ \\
\hline Rigors & 1 & 1 \\
\hline Fever & 0 & 0 \\
\hline Headache, light headedness & 1 & 2 \\
\hline Flushing or any other skin eruption & 0 & 1 \\
\hline Itching & 3 & 2 \\
\hline Hyper/hypotension, & 0 & 0 \\
\hline Chest pain, breathlessness & 0 & 0 \\
\hline $\begin{array}{l}\text { Injection site problem. e.g. pain, } \\
\text { redness etc. }\end{array}$ & 5 & 3 \\
\hline Nausea, vomiting, diarrhea & 2 & 0 \\
\hline $\begin{array}{l}\text { Sever life threatening anaphylactic } \\
\text { reaction }\end{array}$ & 0 & 0 \\
\hline
\end{tabular}

Table 6: Average length of hospital stay.

\begin{tabular}{|ll|}
\hline Groups & $\begin{array}{l}\text { A verage No. of } \\
\text { days }( \pm \text { SD })\end{array}$ \\
\hline Iron sucrose mild anemia group $(\mathrm{n}=30)$ & $3.5( \pm 1.2)$ \\
\hline $\begin{array}{l}\text { Iron sucrose moderate anemia group } \\
(\mathrm{n}=20)\end{array}$ & $9.8( \pm 1)$ \\
\hline FCM mild anemia group $(\mathrm{n}=30)$ & $2.4( \pm 0.5)$ \\
\hline FCM moderate anemia group $(\mathrm{n}=20)$ & $4.5( \pm 1.4)$ \\
\hline
\end{tabular}

\section{DISCUSSION}

World Health Organization recommends $\mathrm{Hb}$ concentration value of minimum $11 \mathrm{gm} \%$ during pregnancy and in peripartum period. According to this definition incidence of anemia is very high in developing tropical countries like ours where it remains a major contributing factor to maternal morbidity and mortality and also high perinatal mortality. Rapid improvement in $\mathrm{Hb}$ and iron stores in postpartum patients will improve general health status of the patient and decreases complications.

There are various iron preparations available for administration but differs in their efficacy and safety profile. In our study we have compared two newer parentral iron preparations iron sucrose and ferric carboxymaltose for the treatment of iron deficiency anemia in postpartum patients. Both these compounds are equally safe and effective in rapidly improving $\mathrm{Hb}$ levels and iron stores in postpartum patients. We have used fixed doses $500 \mathrm{mg}$ and $1000 \mathrm{mg}$ for mild and moderate anemia group respectively because that is near to patients required dose and; logistically easy to administer. Despite higher acquisition costs (as fewer administrations are needed), treatment with ferric carboxymaltose seems to be cost-effective when compared to iron sucrose, and is more convenient for patients and reduces hospital stay, helps in decreasing burden on health care resources.

In the developed world it has long been documented that intravenous iron supplementation is highly effective in treating IDA in a variety of settings, including pregnancy and postpartum. There is irrefutable evidence that compared to oral iron, IV iron results in a much more rapid resolution of IDA, has minimal side-effects, and because it is administered intravenously, it circumvents the problems of compliance. ${ }^{10}$ So we have tried to treat IDA with these two newer compounds, both found to be equally effective. We deliberately did not seek to calculate the optimal iron dose for each woman based on her $\mathrm{Hb}$ level: we simply sought to assess response to a uniform dose in all women whose $\mathrm{Hb}$ fell between 7-11 $\mathrm{g} / \mathrm{dl}$, with an eye to the long term possible adoption of a single universal dose that might go a long way treating IDA in various patients.

\section{CONCLUSION}

Intravenous iron therapy with iron sucrose and ferric carboxymaltose is equally effective in treating mild and moderate postpartum iron deficiency anemia in postpartum patients. Using fixed dose avoids cumbersome TDI calculation and prevent wastage of resources (drug). Ferric carboxymaltose group has better patient satisfaction and required less hospital stay.

\section{ACKNOWLEDGEMENTS}

We sincerely acknowledge all the faculty and staff of department of obstetrics and gynecology, Smt. Kashibai Navale Medical College \& General Hospital for all the help and support for this study.

Funding: No funding sources

Conflict of interest: None declared

Ethical approval: The study was approved by the institutional ethics committee

\section{REFERENCES}

1. Bhatt R. Maternal mortality in India, FOGSI-WHO study. J Obstet Gynecol India. 1997;47:207-14.

2. F. Gary Cunningham. Hematological disorders. In: F. Gary Cunningham, eds. William's Obstetrics. 22nd ed. New York. McGraw Hill; 2005: 1144-1145. 
3. Seid Melvin H. Derman, Richard J. Baker, Jeffrey B. Banach, Warren Goldberg, Cynthia Rogers, Ralph. Ferric carboxymaltose injection in the treatment of postpartum iron deficiency anemia: a randomized controlled clinical trial. Am J Obstet Gynecol. 2008:199(4):435e1-7.

4. Beard J, Hendricks M, Perez E, Murray-Kolb L, Berg A, Vernon-Fegans L. Maternal iron deficiency affects postpartum emotion and cognition. J Nutr. 2005;135:267-72.

5. Somadatta P, Reddiaha VP, Singh B. Prevalence of anemia in postpartum period: a study of North Indian village. Trop Doct. 2009 Oct;39(4):211-5.

6. Borche DE, Gay C, Armand-Branger S, Grangeasse L, Terzibachian JJ. Severe anemia in postpartum period. Clinical practice and value of intravenous iron. Gynecol Obstet Fertil. 2004;32:613-9.
7. Scott B. Silverstein, George Rodgers. Parenteral iron therapy options. Am J Hematol. 2004;76:74-8.

8. Hallak M, Sharon AS, Diukman R, Auslender R, Abramovici. Supplementing iron intravenously in pregnancy. A way to avoid blood transfusions. J Reprod Med. 1997;42(2):99-103.

9. Christian Breymann. The Use of iron sucrose complex for anemia in pregnancy and the postpartum period. Semin Hematol. 2006;43(Suppl 6):S28-31.

10. Crichton R, Danielson B, Geisser P. Iron therapy. In: Crichton R, Danielson B, Geisser P, eds. A Book. 1st ed. Bremen, Germany: Uni-Med Verlag; 2005.

DOI: $10.18203 / 2320-1770$. ijrcog20150071

Cite this article as: Hol KV, Damle H, Shekhawat GS Hol A. Comparative study of intravenous iron sucrose versus ferric carboxymaltose for the treatment of iron deficiency anemia in postpartum patients. Int $\mathrm{J}$ Reprod Contracept Obstet Gynecol 2015;4:669-73. 